\title{
DAKOTA FOLK SONGS AND THEIR INNER-ASIAN CONNECTION
}

\section{János SiPos}

Institute for Musicology of the HAS

Táncsics M. u. 7, H-1014 Budapest, Hungary

E-mail: sipos@zti.hu

\section{Acta}

Ethnographica

IInoarica

\section{SEPARATUM}

\section{AKADÉMIAI KIADÓ}




\section{Acta Ethnographica Hungarica}

\section{AN INTERNATIONAL JOURNAL OF ETHNOGRAPHY}

This journal publishes contributions describing recent scientific advances in the field of ethnography, folklore, and cultural and social anthropology. Emphasis is laid on subjects related to Hungarian ethnography and folklore as well as on works presenting Hungarian folklore in the context of Eastern European and Eurasian cultures. Papers are in English, French, German, and Russian.

$\square$

Abstracted/indexed in Bibliographie Linguistique/Linguistic Bibliography, Elsevier GEO Abstracts, International Bibliographies IBZ and IBR, MLA International Bibliography, SCOPUS, Sociological Abstracts,

Worldwide Political Science Abstracts.

$\square$

Editorial correspondence

www.akkrt.hu/journals/aethn 


\title{
DAKOTA FOLK SONGS AND THEIR INNER-ASIAN CONNECTION
}

\author{
János SiPos \\ Institute for Musicology of the HAS \\ Táncsics M. u. 7, H-1014 Budapest, Hungary \\ E-mail: sipos@zti.hu
}

\begin{abstract}
In 2004-2005 with the help of a Fulbright scholarship the author studied the folk music of two Native American tribes, the Dakota and the Navajo. The article presents the main characteristics of the Dakota folksongs (scales, range, rhythm, melodic movements) and their classification. The author calls the attention to the most characteristic similarities and differences between Dakota songs and the TurkMongolian folk music and shows a descending pentatonic "quintile-shift" melody group whose specific forms blossom in the Dakota, Mongolian, Hungarian and Cheremis-Chuvash folk music.
\end{abstract}

Keywords: Dakota, Hungarian, and Turk-Mongolian folk music, ethnomusicology, classification

Is there any relationship between the folk music of some American Indians tribes and the folk music of Turkic, Mongolian or Hungarian people? Or is this question a nonsense? Not at all, since the ancestors of the American Indians had moved to the Western hemisphere form Asia in a series of migrations; and from Alaska they spread east and south. ${ }^{1}$

And another question: what does a Hungarian ethnomusicologist take the liberty from to say something on the folk music of American Indians, especially as according to Nettl (1954: VI):

During the first half of the twentieth century, aboriginal North America has become the continent of primitive cultures whose music has been the most extensively studied and is best known. ${ }^{2}$

Indeed, American scholars and amateurs made enormous researches among Native Americans; as the joke says the smallest Indian family had five members: father, mother, two children and an anthropologist. Is there any need then for a Hungarian scholar to gnaw

${ }^{1}$ American Indians do not like this theory because it contradicts their myths. Of reason of this disliking is that if they had come from another continent they could have been treated as 'immigrants'.

${ }^{2}$ NETTL: 1954. 
off gnawed bones? The answer to this question is also positive. Hungarian and American scholars use different methods, and a Hungarian comparative musical analysis might bring forth important results in ethnomusicology, and may even give new results on the origin of the Indians. The thorough knowledge of the Turkic, Mongolian and Hungarian folk music is not a disadvantage either.

Hungarian ethnomusicologists searching for the eastern relations of Hungarian music made significant efforts exploring the folk music of the Volga-Kama region and that of Turkey. ${ }^{3}$ Later the area of the research was extended to Azeri, Kazakh, Kyrgyz, Karachay, Mongolian and other peoples as well. ${ }^{4}$

It was known that similarly to many Turkic and Mongolian peoples, the melodies of many Native American tribes move on pentatonic scales. This fact motivated some Hungarian researchers to collect among Native Americans, though these researches were carried out only in South-America and were not too extensive either. ${ }^{5}$

In 2004-2005 as a Fulbright scholar at the Department for Ethnomusicology of UCLA I had the opportunity to study the folk music of two Native American tribes, the Dakota and the Navajo. I started my work with transcribing and analyzing many hundreds of Dakota songs collected by Willard Rhodes in 1939-1941 in Pine Ridge, Montana. ${ }^{6}$

I was ready to do field work. My university colleagues warned me not to visit Indians; You will not be able to collect melodies from them - they said. It was clear that white men do not have a good reputation among Native Americans. However, I had a great advantage: I am not American, Spanish, English or French. Being the son of a smaller nation it is easier to play ball with another small and oppressed people.

I had another difficulty: songs have special importance for the Indians, they are often personal or tribal property and Indians do not easily give them out. One may not use someone else's songs without first having been given those songs, or at least the right to use them. This is usually accomplished by giving a gift to the song's owner. Today, as it was in the past, many Indian song makers say that the inspiration for their songs is acquired through dreams or visions. It is said that often a song maker will hear a song in a dream, and will wake up singing it. ${ }^{7}$ Certain songs and ceremonies, such as Navajo blessing chants, must be performed precisely. Any deviation or errors in the words or music negate the power of the song and the whole process must either be abandoned or restarted from the beginning. In other words, a song accompanying a religious ceremony not only sets the mood for the worshippers, but carries power in itself.

Despite of all these difficulties I carried out nice field-works among both Navajo (300 songs) and Dakota Indians (250 songs). Navajos are today the largest East American Indian tribe; they speak their own language and keep their culture alive to a large extent. In 2004 2005 we started a research series among them with Jerry L. Jaccard, the Vice-President of the International Kodály Society, who used to be a teacher in the Four Corner Navajo reservation for a longer period.

\footnotetext{
${ }^{3}$ Béla Bartók in Turkey (1936); László Vikár and Gábor Bereczki among Finno-Ugrian and Turkic ethnic groups living in the Central Volga Region (1958-1979).

${ }^{4}$ Sipos $(1994 ; 1995 ; 2000 ; 2001 \mathrm{a} ; 2001 \mathrm{~b} ; 2002 ; 2004)$.

${ }^{5}$ HALMOS: 1979; ÖRDÖG: 1997.

${ }^{6}$ This material is in the Archives of Ethnomusicology, UCLA.

${ }^{7}$ BIERHORST: 1979, p. 5.
} 
The reason of choosing the Dakotas was different. Most ethnomusicologists accept the important place of northern Indian music among the American Indian styles, and this music plays an outstanding role in contemporary powwows as well. Here, too, I needed someone to introduce me into a Dakota community. A Dakota man, Dwight Youpee, who worked at the Department for American Indian Studies (UCLA) made friends with me, and recommended me to his acquaintance in the Fort Peck Community College. In November 2004 I flew from Los Angeles to Salt Lake City with a giant airplane, from there to the north, to Billings with a much smaller one, and from there with a tiny aircraft with ten seats to Wolf Point, where my helper, Adrian Spotted Bird was waiting for me.

These wonderful people put me up, sung their songs, introduced the musical repertoire of their ceremonies, they even invited me to sing with them in the sweat lodge and smoke the pipe of peace. The time I spent among them will remain one of the most remarkable memories of my staying in America. Though there were serious alcohol and drug problems in the reservation, I was bewitched by the philosophical and emotional greatness of the Indian intelligentsia.

Let me say now a few words on the music of the North American Indians. The common origin of the Amerindians explains the physical characteristics that Amerindians have in common, while the several waves of migration are supposed to account for the many native linguistic families. ${ }^{8}$

There are lots of common characteristics of the music of the different North-American Indian tribes. Common is the descending melodic line, the pentatonic scales and frequent is the vocal tension. At the same time there is a great diversity of musical styles. These can generally be grouped into divisions which follow roughly the major cultural areas. Naturally, where cultural areas meet and overlap, there is a sharing of characteristics. However, some areas developed more or less independently for several centuries (e.g. Southwest and California or the Great Basin). ${ }^{9}$

There are several publications on the music of the Dakota people. ${ }^{10}$ From these I mention

\footnotetext{
${ }^{8}$ Charles and Florence Voegelin keep in evidence 221 different languages only in North-America (VOEGELIN - VOEGELIN: 1966).

${ }^{9}$ One division of the main areas is as follows: 1. Eastern Woodlands, 2. Great Plains (northern and southern), 3. Southwest, 4. Great Basin, 5. California-Yuman, 6. Northwest Coast, 7. Arctic. See also Herzog: 1928; RoBerTs: 1936 and NeTtL: 1954.

${ }^{10}$ PowERs: 1990; JURRENS: 1965. The first important study with a number of transcriptions was written by Baker in 1882 (BAKER: 1882: reprint publication with English translation (by Ann Buckley): On the Music of the North American Indians, The Netherlands, 1976. Carl Stumpf wrote the first comparative musicology study on the music of one tribe with only 9 songs included (STUMPF: 1886). Many collections of Indian songs were published with transcriptions but without musical analysis, e.g. CurTis-BurLIN: 1907; CurTis: 1907-1930; Densmore and Rhodes described the study of Indian music in the nineteenth century (DENSMORE: 1927; RHODES: 1952). The German comparative musicologists Abraham and Hornbostel wrote one monograph on the music of the Thompson River Indians (ABRAHAM - HoRnBostel: 1906). During the nineteenth and early twentieth century a large amount of melodies was collected, some of them were published but usually without transcriptions and musical analysis. Some important publications: MoOnEy: 1896; Cringan: 1899; MatTHEws: 1892; BOAS: 1888. In the first half of the twentieth century the most important field workers were Frances Densmore, Helen H. Roberts and George Herzog. Densmore concentrated mainly on Plain Indians making a huge amount of recording, transcriptions and analysis. Helen $\mathrm{H}$. Roberts was the first who tried to give the entire picture of North American Indian Music. NETTL (1954: vii) questions her musical areas but accepts her study among the
} 
two, containing many transcriptions and some analysis as well. Frances Densmore 1918) did a complete analysis of the Teton Dakota of the Eastern part of the state of South Dakota and Juries 1965) investigated the music of the Dakota Indians of the Rosebud Reservation.

Analyzing the Dakota songs I used the songs in the Rhodes collection and those collected by myself. First, let us have a glance at the scales, the range, the rhythm and the melodic movements. For lack of space in this paper I discuss only Dakota melodies moving on the A'-(G)-E-D-C-A la penta- or tetratonic scale.

Scales and range. As we have already mentioned the interest of the Hungarian scholars was aroused by the pentatonic character of the American Indian music. However, in the Rhodes collection a remarkable phenomenon was to be observed. In contrast to the A-pentatonic scale in many Asian melodies the majority of the Dakota songs in the Rhodes collection are moving on the (A')-E-D-C-A tetratonic scale. ${ }^{11}$

Nonetheless, the intonation of the tones in the scales might be strange to an ear being accustomed to European music (though not to the connoisseurs of different Inner Asian musics). As John Bierhorst, a writer and compiler of information about Indian culture explains:

"... just as in the music of the birds, Indian music does not always keep to the fixed tones that can be played on the piano. Some notes are actually quarter tones - in between the half tones on the piano. Here and there a note may be made up of several tones, like a syllable of ordinary speech."

The Northern Plain singers usually sing with a certain amount of tension in the throat and vocal chords.

Rhythm and meter. In contrast to the most characteristic Asian musical styles many Dakota (and generally North American Indian) songs do not fit any standard 3/4 or 4/4 time signatures; a different time signature must be used for nearly every measure. "Putting these songs into notation is like putting them into a straitjacket."12 At the same time songs connected with dances tend to have more of what might be called body rhythm, that regular foot-tapping kind of beat. ${ }^{13}$ Singers do not always mark the beginning or the end of musical phrases with accents, long notes or pauses. Having equal intensity, the drumbeats do not help to define the structure of the songs either. $6 / 8(3+3)$ and its extension to $9 / 8$ $(3+3+3)$ are common time signatures but here, too, we often are in trouble as to where to put the bar lines. ${ }^{14}$ Similarly, the rhythmic formulas in different sections of Dakota songs

most important in the field (ROBERTS: 1933; ROBERTS: 1936). George Herzog wrote shorter but very important studies in North American Indian music (Herzog: 1928; Herzog: 1938). Bruno Nettl drew the overall North American Indian musical styles admitting that "It is perfectly conceivable that the present scheme of musical areas will have to be revised soon because of new finds" NETTL: (1954). The rhythm of the Redman is brought out in the books by Hodge (1969); HiRSHBERg (1917); ButTrEe (1930).

${ }^{11}$ Many contemporary melodies sung in powwows and the reservations moves on the (C')-A'-G'-E-DC-A la-pentatonic scale.

${ }^{12}$ BIERHORST: 1979, p. 6.

${ }^{13}$ BIERHORST: 1979, p. 6.

${ }^{14}$ We might use triplets or changing $2 / 4$ and $3 / 4$ time signatures as well. The special metric and rhythmic 
might differ considerably. Also, there are only a few isometric and/or isorhythmic Dakota songs.

The texts are usually not strophic; meaningful words alternate vocables and many texts contain exclusively vocables without exact meaning but are sung the same way every time. Most probably American Indians do not feel the necessity to use many words because a few words can satisfactorily express a widely known idea or event. This phenomenon above is frequent in Inner Mongolian folk songs too, but rare in the folk music of Turkic or Hungarian peoples.

A remarkable phenomenon is that drummer and singer start out and end together, but the rhythm of the vocal and the drum may shift from each other throughout the song. The vocal part sings ahead of the drumbeats for a while, as they say at the powwows they 'sing off the beat'. A similar but not identical kind of rhythmic shift can also be seen in various forms in the folk music of different peoples. As an example, the fiddler of a Hungarian gypsy band often plays an eights value ahead of the band but not later than at the end of each song it rejoins the accompaniment. Though here we cannot imagine any genetic relations, the examination of this rhythmic phenomenon in different musical words would be important.

In Dakota folk music, the drum often stresses the weak parts of the bars: in binary measure it beats $i \delta$. This phenomenon is well known in other parts of the world too, though not in Inner Asia. A more specific Amerindian phenomenon is that the drum beats i $\delta \delta$ i $\delta \delta$ rhythm not only in $6 / 8$ but also in $2 / 4$ time signature. ${ }^{15}$ As if Dakota people sometimes would feel triple pulsation in even-numbered bars as well. I observed this beautiful and original phenomenon in several of the melodies of the Rhodes collection, but not in the newer recordings.

Melodic line. The melodic movements of the Dakota songs obey some general rules. The descending tendency and the tetratonic scale limit the number of possible steps. Melodies often begin on the tonic then jump up to the fifth or even to the octave. Inside sections typical melodic movements are recitation on a tone or one or two steps in the same direction followed by a step back. In contrast, Middle-Asian pentatonic melodies are characterized by more vehement melodic movements. At the beginning and at the end of the Dakota melodies we often hear sound-repeating initial and closing formulas. Repetitions of melodic sections are usually very accurate, except at the beginning of the melody which tends to be changed or even omitted.

Let me now introduce the central melodies, which characterize the whole material best. As criteria for the classification I choose the cadences (last note of the melodic sections) and the range of the melodies. ${ }^{16}$

freedom of the Dakota songs might be looked upon as a kind of frozen free rhythm. The strict tempo is obligatory because the American Indians often dance while singing these songs. A great variety of meters and rhythmic patterns are possible because the structures of the dances are very free. Dancers do not have to regulate their dance to musical structures, so music has freedom to create rhythmical and structural variations.

${ }^{15}$ Seemingly similar is the rhythm of the Valcer of Vienna, but here the function and the inner rhythm of the accompaniment is basically different.

${ }^{16}$ Cadences are the last note of the melodic sections. 


\section{A. Melodies with narrow ranges}

There are melodies moving on 3 or 4 tones: (E)-D-C-A. These melodies may differ from each other considerably and probably represent different old layers of the Dakota folk music. Simplest is a story song reciting on $\mathrm{C}$ then descending to $\mathrm{A}$, and some lullabies moving up and down on the D-C-A triton sometimes reaching $\mathrm{E}$ as well. The majority of these basic songs built up of two short repeated sections with $\mathrm{C}$ or $\mathrm{D}$ cadences have a descending character $(E x, 1)$.

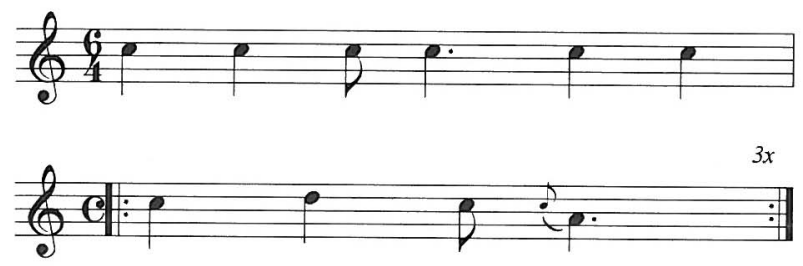

Example 1. Narrow-range melody

\section{B. The central musical style (descending an octave)}

The melodies of the most important central musical style are characterized by different realizations of an octave descent.

\section{Steady descent in one section ( + an additional descent)}

Lots of Dakota melodies descend an octave from A' to A without an interruption by long notes, repeated notes or longer breaks. The second half of the melody usually shows a descent from D or E. (Ex. 2)
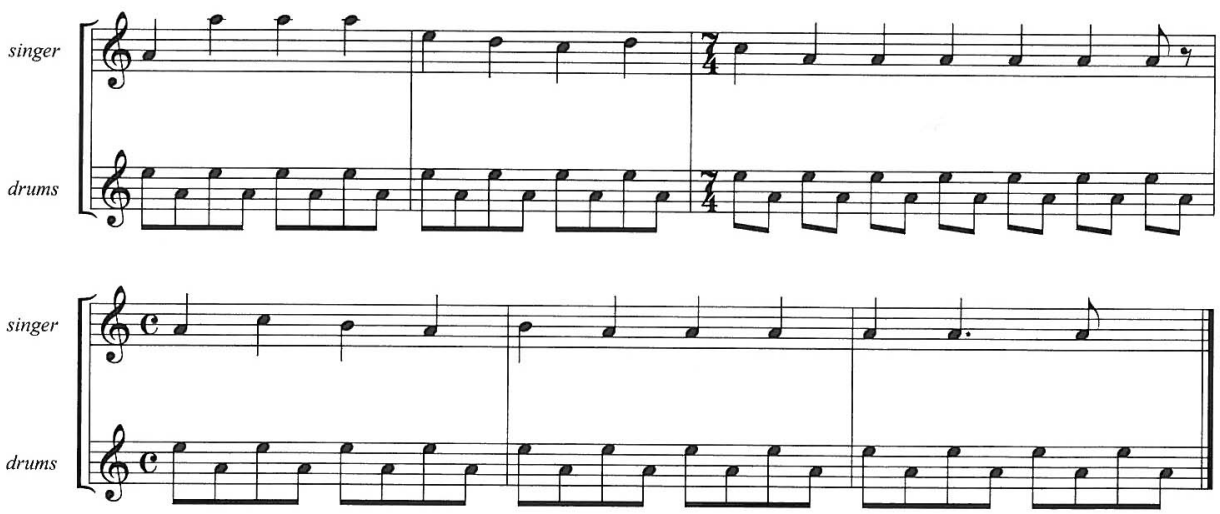

Example 2. Steady descent on an octave

\section{Descent with inner cadence-two-section melodies}

There are melodies with two different sections, where the first section descends from $A^{\prime}$ to a middle sustained or repeated cadence note (C, D or E). The second section descends from A' or E to the tonic. Ex. 3 is seemingly three-sectioned, but the third section only reassures the closing formula at the end of the second section. 

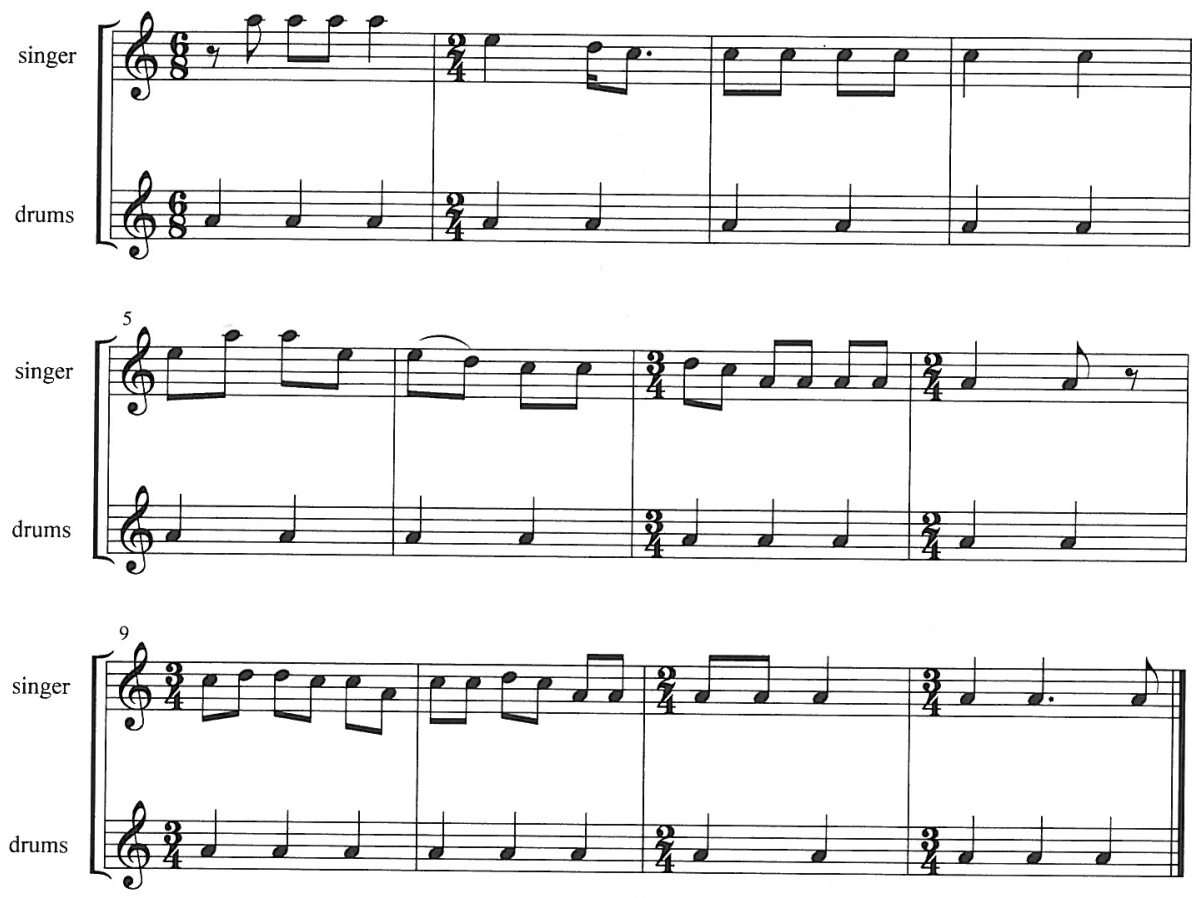

Example 3. Two-section melody with repeated C cadence note (5-14)

\section{Three-section melodies}

Often accurate $\mathrm{E}$ and $\mathrm{C}$ (or $\mathrm{E}$ and $\mathrm{D}$ ) repeated cadence notes divide the octave-descent into three balanced parts. (Ex. 4)
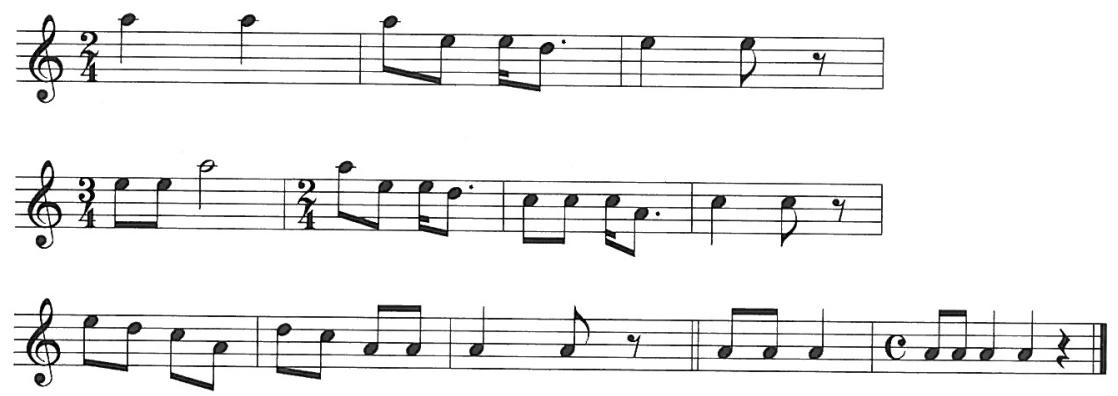

Example 4. Three-section melody with E-C-A cadences (18-15) 


\section{Four-section Dakota and Hungarian melodies}

In Dakota folk music the four-section form is relatively rare and the genre of these melodies is usually 'love song'. They have descending character too, the descent beginning from the octave. According to the cadences there are five different groups of these songs. ${ }^{17}$ The first sections usually move in the upper half of the octave, the middle sections in the middle register and the last sections in the lower register of the octave. In the next table we compare some characteristics of the Dakota and Hungarian songs. ${ }^{18}$

\begin{tabular}{|l|l|l|}
\hline & \multicolumn{1}{|c|}{ Dakota } & \multicolumn{1}{|c|}{ Hungarian } \\
\hline tone set & tetratonic & pentatonic \\
\hline sections & descending & descending \\
\hline motifs & $\begin{array}{l}\text { A-A'-E-D, E-A'-E-D or A-D-C-A, E-D-C-A, } \\
\text { less frequently A'-D-C }\end{array}$ & $\begin{array}{l}\text { A'-G'-A'-E, A'-G'-E-A', G'-A'-E-C, D-C-D-G, } \\
\text { C-D-C-G (G playing a more important role) }\end{array}$ \\
\hline
\end{tabular}

Now, let us see two representatives of the four-sectioned Dakota melodies and their Hungarian parallels (Ex. 5a,b).

a)
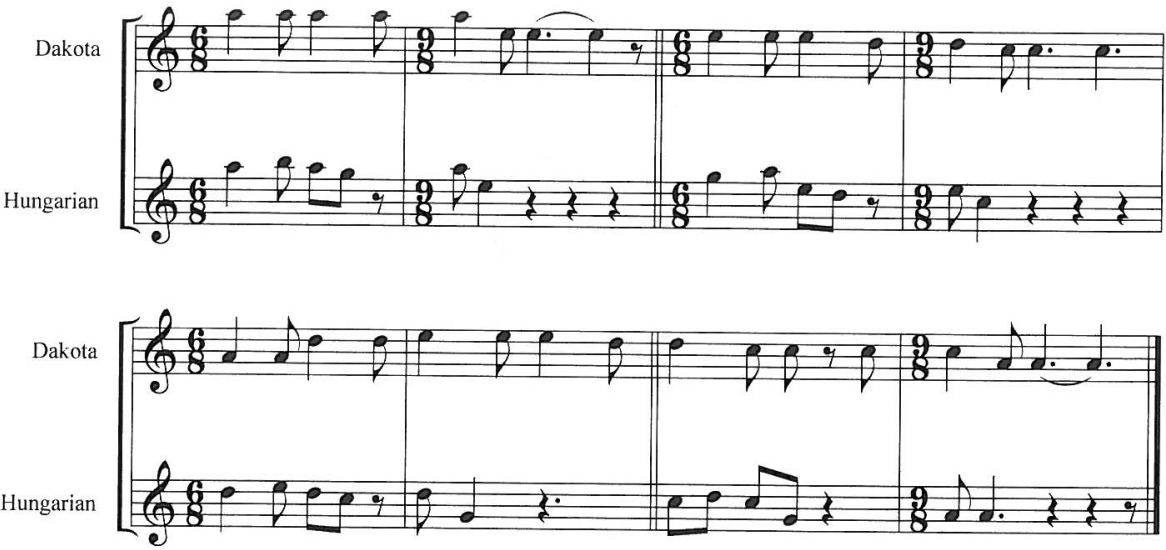

b)

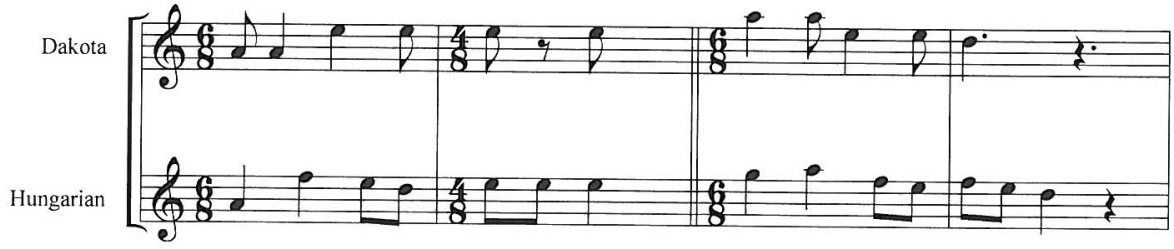

17 The cadence sequences are as follows: E-C-D-A, E-D-C-A, A-D-D-A, A-E-D-A, A-E-C-A. Let us remember that now we are only discussing melodies moving on A-pentatonic scale.

${ }^{18}$ As we saw earlier, Dakota songs do not use the $G$ tone, which plays an important role in Hungarian melodies. In Hungarian melodies sometimes $\mathrm{F}$ appears between $\mathrm{E}$ and $\mathrm{A}$, hiding the pentatonic character. In the closing sections of Hungarian melodies $\mathrm{Bb}$ can also often be heard. 


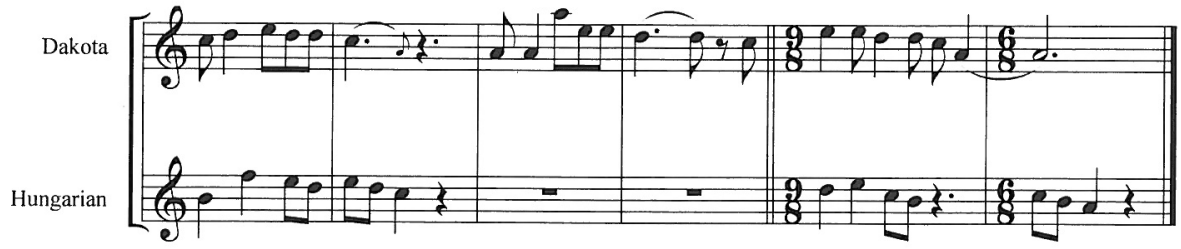

Example 5. Four-part Dakota melodies and their Hungarian parallels. a) Dakota melody with E-C-D cadences (9-14) and a Hungarian parallel 16-029-00-01), ${ }^{19}$ b) Dakota melody with E-D-C cadences (7-23a) and a Hungarian parallel (17-122)
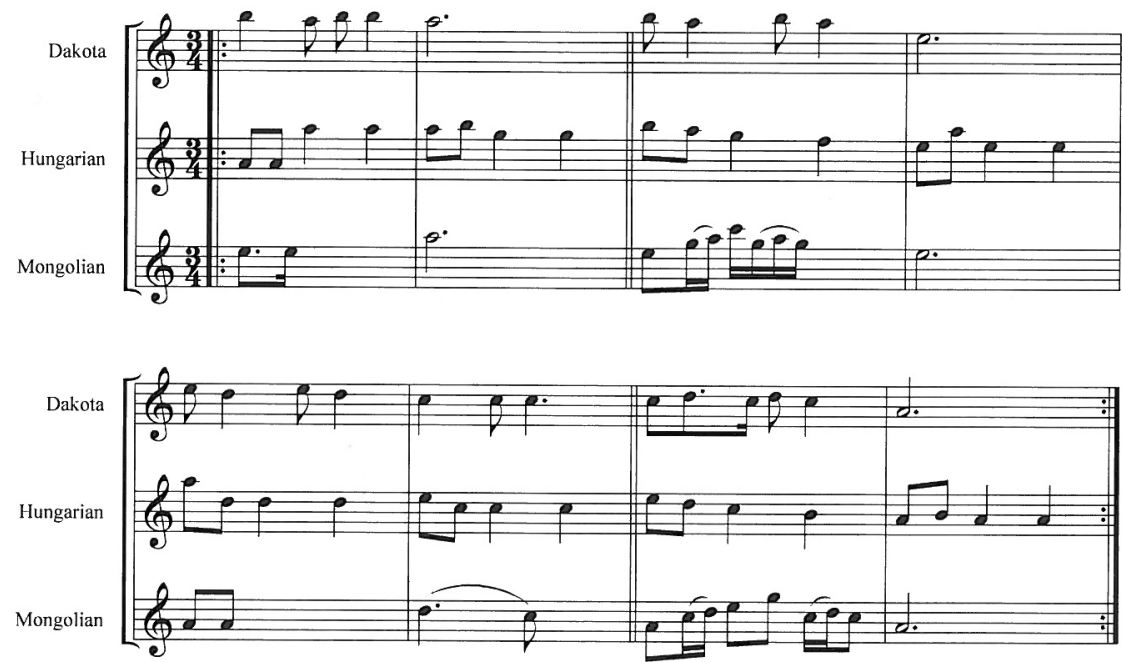

Example 6. Fifth-shifting Dakota melody with A'-E-C cadences (26-2) - Hungarian variant (18-018) - Mongolian parallel (MO1-94)

\section{Fifth-shifting Dakota, Hungarian and Mongolian melodies}

The fourth type of the four-sectioned songs has a special importance as they have a disjunctive structure: the first part moving in the upper half of the octave with a cadence on E, and the second half moves in the lower part. In this way, they show some similarities to some pentatonic fifth-shifting Mongolian, Tatar, Chuvash and Hungarian melody types. Within the scope of the present study, we cannot compare the Dakota, Hungarian and Mongolian fifth-shifting styles in details, only a few examples are provided here $(E x .6) .{ }^{20}$

${ }^{19}$ The numbers after Dakota songs refer to the number of the CD and the track of the digitized Rhodes 1939 collection in the UCLA Ethnomusicology Archives. The number after the Hungarian songs refers to the ID number of the Hungarian melody type.

${ }^{20}$ I compared Hungarian, Cheremis, Chuvash, Mongolian and Chinese fifth-shifting styles in detail in Sipos (2001c). 


\section{Melody types with larger range}

There are a limited number of Dakota melodies with a range wider than an octave. ${ }^{21} \mathrm{As}$ an example I show a four-sectioned melody with A'-E-C-A cadences (Ex. 7).

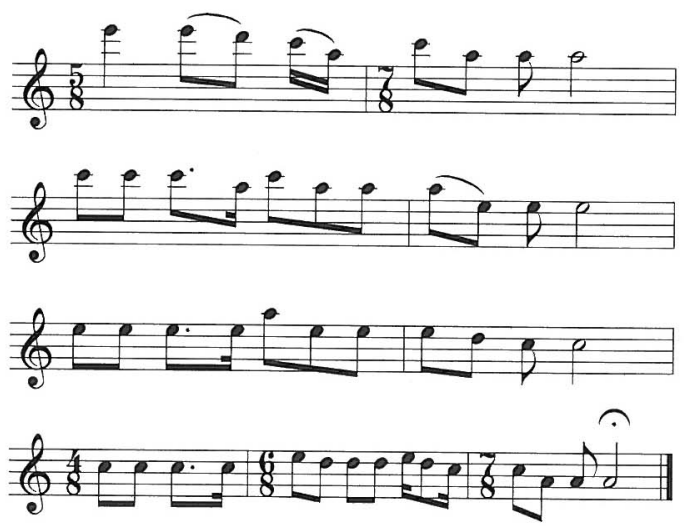

Example 7. Melodies with large range: four-section melody with A'-E-C-A cadences (23-9)

\section{Conclusion}

Are there similar musical layers in Dakota, Hungarian and Mongolian folk music? These songs move on similar scales with a descending tendency, what is more there are four-section and even fifth-shifting melody parallels as well. ${ }^{22}$ However, in many cases rhythm, melodic and motif structure show considerably different features. One of the most important differences is that while the sections of Dakota songs show a continuously descending character, ${ }^{23}$ Inner Asian pentatonic songs are often built up from motifs.

Are these differences the consequence of the separation of a one-time common musical culture or are they an accidental similarity between two musical cultures that have never had any contact with each other? The science of ethnomusicology is not yet able to answer this question with certainty. However, the musical analysis above allows the possibility of the Asian origin of certain (four-sectioned) Dakota musical layers. Therefore, we may consider these melodies as slightly different realizations of a common musical base.

Though the majority of A-pentatonic Dakota melodies belong to the same musical style, Dakota music is a significant creation characterized by homogeneous and clear forms, just as all great musical styles are. ${ }^{24}$

${ }^{21}$ Thirteen melodies out of the total 200. This portion is much higher in the material I collected in 2004.

${ }^{22}$ It is thought provoking that we have found most of the similarities among the four-section songs. It would be more logical to find similarities among songs having simpler forms too.

${ }^{23}$ Not counting the jumping up movements at the beginning of some Dakota melody sections.

${ }^{24}$ This musical world is more homogeneous and simple than that of the Hungarian or Anatolian. 


\section{LITERATURE}

MO1: Joo-uda arad-un daruu, Köke Qota, 1981

MO2: Öbör mongyol-un Arad-un Keblel-ün Qoriy-a, Köke Qota, 1981

MO3: $\quad$ Aju bajindal jang jangsil-un dayuu, Köke-Qota, 1981

MOE: $\quad$ Mong $\gamma$ ol arad-un ming $\gamma$ an dayuu, Vol 2

MOSH: Emsheimer, Music of Eastern Mongolia, collected by Haslund-Christensen. In: Reports from the scientific expedition to the north-western provinces of China under the leadership of dr. Sven Hedin, VIII. Ethnography 4, The Music of Mongols, Stockholm, 1943

AвRAHAm, O. - Hornbostel, E. M. von

1906: Phonographierte Indianermelodien aus British Columbia. In: Boas Anniversary Volume, New York

BAKER, T.

1882: Über die Music der nordamerikanischen Wilden, Leipzig, 1882. Reprint edition with English translation by Ann Buckley: On the Music of the North American Indians, The Netherlands, 1976

BARTÓK, B.

1924: A Magyar népdal [The Hungarian Folksong], Budapest

BIERHORST, J.

1979: A Cry From the Earth, New York, Four Winds Press

BOAS, F.

1888: The Central Eskimo, Washington

BUTTREE, J. M.

1930: The Rhythm of the Redman, New York, The Ronald Press Company, p. 192.

Cringan, T. A.

1899: Music of the Pagan Iroquois, Archaeological Reports, Appendix to the record of the Minister of Education, Toronto, pp. 166-180.

CurTIS, S. E.

1907-1930; The North American Indian, 20 vol., Norwood, Mass.

Curtis-Burlin, $\mathrm{N}$.

1907: The Indians` Book, New York and London

DENSMORE, $\mathrm{F}$.

1918: Teton Dakota Music, Bulletin No.61 of the Bureau of American Ethnology, Washington D.C.

Densmore, $\mathrm{F}$.

1927: The Study of Indian Music in the Nineteenth Century, American Anthropologist, 29

HALMOS I.

1979: The Music of the Nambicura Indians (Mato Gross, Brazil). Acta Ethnographica Academiae Scientarium Hungaricae, Tomus 28 1-4. pp. 205-350

HerzoG, G.

1928: Musical Styles in North America, Proceedings of the 23rd International Congress of Americanists, pp. $455-458$

Herzog, G.

1938: A Comparison of Pueblo and Pima Styles, Journal of American Folklore, 49

FREDERIC, W.

1969: Handbook of American Indian North of Mexico, New York, Pageant Book, Inc. pp. 959-960

HIRSHBERG, D. K.

1917: Rhythm of Indian Songs, Musician, April, p. 257

HoDGE, F. W.

1969: Handbook of American Indian North of Mexico, New York, Pageant Book, Inc.

JuRRENS, J. W.

1965: The Music of the Dakota Indian of the Rosebud Reservation in South Dakota and Its Use in the Elementary School (Research Study No. 1), Greeley, Colorado, Colorado State College 
KODÁLY, Z.

1937-1976: A Magyar népzene [Folk Music of Hungary] (1st edition 1937, 7th ed. revised and enlarged by

LIGETI, L.

L. Vargyas Budapest, 1976)

1933: Rapport préliminaire d'un voyage d'exploration fait en Mongolie Chinoise 1928-1931, Budapest

Matthews, W.

1892: Navaho Legend, New York

MOONEY, J.

1896: The Ghost-Dance Religion and the Dakota Outbreak of 1890, Washington

NeTTL, B.

1954: North American Indian Musical Styles, Memoirs of the American Folklore Society, Vol. 45, Philadelphia ÖRDÖG, L.

1997: Ének-zene az általános iskolák 6. osztálya számára [Music for the $6^{\text {th }}$ class of elementary schools], Budapest

POWERS, W. K.

1990: War Dance: Plains Indians Musical Performance, Tucson and London, University of Arizona Press

RHODES, W.

1952: North American Indian Music, Notes, 10, pp. 33-45

RoBERTS, H. H.

1933: Form in Primitive Music, New York

ROBERTS, H. H.

1936: Musical Areas in Aboriginal North America, New Haven

SIPOS, J.

1994: Török népzene I [Turkish Folk Music I], Budapest

1995: Török népzene II [Turkish Folk Music II], Budapest

2000: In the Wake of Béla Bartók in Anatolia, Budapest

2001a: Kazakh Folksongs from the Two Ends of the Steppe (with CD), Budapest

2001b: Report on my Expedition in the Caucasus. In: Néptörténet-Nyelvtörténet, A 70 éves Róna-Tas András köszöntése, pp. 155-184. Szeged

2001c: Egy most felfedezett belső-mongóliai kvintváltó stílus és magyar vonatkozásai [A recently discovered fifth-shifting style and its Hungarian aspects], Ethnographia 1-2, 112, pp. 1-80, Budapest

2002: Bartók nyomában Anatóliában [In the wake of Béla Bartók in Anatolia], Budapest

2004: Azeri Folksongs - At the Fountain-Head of Music, Budapest

Stumpr, C.

1886: Lieder der Bellakula Indianer, Vierteljahrschrift für Musikwissenchaft, 2

SZABOLCSI, B.

1934: Népvándorláskori elemek a magyar népzenében [Elements surviving from the time of the great migrations in Hungarian folk music], Ethnographia XLV, Budapest

SZABOLCSI, B.

1979: A magyar zenetörténet kézikönyve [Handbook of the Hungarian Music History], Budapest

VIKÁR, L. - BERECZKI, G.

1971: Cheremis Folksongs, Budapest

VIKÁR, L. - BERECZKI, G.

1979: Chuvash Folksongs, Budapest

Voegelin, Ch. F. - Voegelin, Fl. M.

1966: Map of North American Indian Languages. (American Ethnological Society Publications 20.) American Ethnological Society, USA 
Our online journals are available at our MetaPress-hosted website:

www.akademiai.com. As an added benefit to subscribers, you can now access the electronic version of every printed article along with exciting enhancements that include:

Subscription

Free trials to many publications

Pay-per-view purchasing of individual articles

Enhanced search capabilities such as full-text and abstract searching

ActiveSearch (resubmits specified searches and delivers notifications when relevant articles are found)

E-mail alerting of new issues by title or subject

Custom links to your favourite titles

Please inform us about your MetaPress ID

in order to prevent any activation problem 


\section{New subject collections available}

Akadémiai Kiadó offers a new suite of electronic-only journals collections with significant pricing discounts. For further details please visit our homepage at www.akademiaikiado.hu/collections 